\title{
RESIKO ERGONOMI DENGAN GEJALA MSDS PADA KARYAWAN PABRIK MIDPER
}

\author{
Edison', Rubi Ginanjar², Supriyanto ${ }^{3}$ \\ ${ }^{1}$ Program Studi Kesehatan Masyarakat Fakultas Ilmu Kesehatan, Universitas Ibn Khaldun Bogor. \\ Email : edisonfikes52@gmail.com \\ 1,2Program Studi Kesehatan Masyarakat Fakultas Ilmu Kesehatan, Universitas Ibn Khaldun Bogor.
}

\begin{abstract}
Abstrak
MSDs merupakan salah satu resiko dari aktifitas menjahit pada pekerja produksi garmen, sepatu, tas, dan jok mobil. Keluhan MSDs dipengaruhi oleh faktor manusia seperti usia, kebiasaan olahraga dan masa kerja. Sedangkan faktor pekerja seperti postur pekerja dan durasi kerja. Tujuan penelitian ini adalah untuk mengetahui hubungan resiko ergonomi dengan gejala MSDs pada karyawan Pabrik Midper di kabupaten Bogor Tahun 2020. Penelitian ini menggunakan studi deskriptif analitik dengan desain cross sectional study. Populasi penelitian ini sebanyak 50 dengan sampel yang sama yaitu 50 responden dengan teknik sample jenuh (dimana seluruh jumlah populasi dijadikan sampel penelitian dikarenakan jumlah populasi berjumlah kurang dari 100 responden). Alat yang digunakan dalam penelitian ini menggunakan lembar kuesioner dan kuesioner REBA pada postur kerja. Cara analisis data penelitian ini menggunakan perangkat lunak aplikasi Statistik (SPSS 23) dengan menggunakan uji statistik chi-square. Hasil penelitian menunjukkan bahwa ada hubungan antara usia ( $p$-value $=0,00)$, masa kerja $(p$-value $=0,00)$, durasi kerja $(p$-value $=0,00)$, kebiasaan olahraga $(p$-value $=0,00)$, postur tubuh $(p$-value $=0,00)$, kebiasaan merokok $(p$ value $=0,00$ ) dengan gejala MSDs pada karyawan karena oleh berbagai sebab yang menyebabkan otot - otot yang berperan dalam mempertahankan keseimbangan seluruh tubuh. Kesimpulan penelitian ini adalah semakin tua usia, masa kerja, kebiasaan olahraga, kebiasaan merokok serta durasi kerja tinggi maka peluang terhadap keluhan nyeri punggung bawah semakin tinggi, Disarankan agar pekerja memanfaatkan waktu istirahat seoptimal mungkin dan melakukan peregangan otot dengan tujuan agar sirkulasi darah tetap lancar.
\end{abstract}

Kata Kunci : Nyeri Punggung bagian bawah, Faktor MSDs, Faktor individu, Karyawan Pabrik Tas Bahan

\section{PENDAHULUAN}

Keselamatan dan kesehatan kerja merupakan aspek penting dalam perkembangan sebuah perusahaan. Akan tetapi, perusahaan biasanya hanya fokus terhadap keselamatan kerja. Padahal, aspek kesehatan kerja juga merupakan hal penting yang tidak boleh diabaikan. Seperti yang tercantum di UU No. 36 Tahun 2009 tentang kesehatan bahwa perusahaan harus melakukan upaya kesehatan kerja untuk melindungi pekerja agar hidup sehat dan bebas dari gangguan kesehatan serta pengaruh buruk diakibatkan oleh pekerjaaan masalah kesehatan yang dapat ditimbulkan dari pekerjaan salah satunya terkait dengan ergonomi.

MSDs merupakan gangguan kronik pada otot,tendon dan saraf yang disebabkan oleh penggunaan tenaga secara repetitf, pergerak cepat penguanan tenaga yang sangat besar, 
kontak dengan tekanan, poster jangal atau ekstrem, getaran temperatur yang rendah (ACGIH,2010) salah satu pekerjaan yang menghadapi resiko MSDs meliputi aktivitas menjahit, seperti pada pekerja produksi garmen, sepatu, tas, jok mobil (OSHA).

Pekerjaan di industri garmen menuntut ketelitian yang cukup tinggi dengan karakteristik pekerja umumnya adalah proses material handlin (angakat-angkut), posisi kerja duduk dan berdiri tingkat pengulangan kerja tinggi pada satu jenis otot, berintaksi dengan benda tajam (jarum, gunting, dan pisau potong), panas di bagian pengepresan dan pembungkusan banyak debu - debu serat dan aroma lain, kebisingan getaran dan lainnya. Permasalahan ergonomi kerja di industri garmen terutama sangat terkait dengan postur tubuh dan pergelangan tangan yang tidak baik dan harus melakukan pekerjaan berulang ulang pada hanya satu jenis otot sehingga sangat berpotensi menimbulkan gangguan musculoskeletal (muslim, 2011).

Peralatan yang digunakan dalam industri pabrik tas biasanya tidak sesuai dengan postur tubuh pekerja sehingga ketegangan pada otot berlangsung sepanjang waktu kerja yang menimbulkan sakit pada bahu, lengan atas lengan bawah, ketinggian bangku yang tidak sesuai menyebabkan harus menundukkan leher dan bungkuk. Sebagai akibat dari berlebihan membungkuk, mayoritas pekerja mengeluh nyeri pada pinggang, punggung, bahu dan leher. Bangku yang digunakan juga tidak mempunyai backrest untuk menahan punggung (Parimalam, 2006).

Berdasarkan data dari Bureau of Labor Stastistic (BLS), kasus MSDs sebanyak 378,820 menyumbang 33 persen dari semua kasus cidera dan sakit pada tahun 2011, lebih lanjut BLS menyebutkan bahwa untuk semua pekerja, cidera punggung menyumbang 42 persen dari terjdinya kasus MSDs dan membutuhkan rata-rata 7 hari untuk pemulihan. Sedangkan cidera pada bagian bahu hanya menyumbang 13 persen dengan waktu pemulihannya sekitar 21 hari (BLS,2012). Selain itu, data yang disebutkan oleh K. Saravana tahun 2011 bahwa 70\% operator mesin jahit dilaporkan mengalami sakit punggung 25\% dilaporkan mengalami low back pain secara persistent, $25 \%$ menderita akibat CTD,18\% mengalami CTD pada perlenganan tangan 14\% mengalami CTD pada bagian siku 5\% CTD pada baian bahu 49\% mengalami sakit pada bagian leher.

Penelitian yang dilakukan oleh Departemen Kesehatan RI pada 7 industri di wilayah industri Pulo Gadung Jakarta Timur menunjukkan bahwa pekerja industri yang mengalami kelelahan nyeri muscoluskeletal sebanyak 502 orang $(52,8 \%)$ dan terbanyak pada industri garmen (65,2\%) (Riyadina 2008). Selain itu, penelitian yang dilakukan oleh Noor Fitrihana pada tahun 2008 menemukan bahwa keluhan muscoluskeletal yang paling dominan dirasakan oleh operator jahit adalah pada bahu 76,6\% ,pungung 65,96\%, pingang 63,8\%, dan leher $6170 \%$.

PT MIDPER adalah salah satu indutri yang bergerak di bidang produksi tas. Pekerja di midper beresiko untuk terkena MSDs karena pekerjaannya yang memerlukan waktu lama dan mempunyai postur jangal serta repetitif disetiap pekerjaanya. Oleh karna itu peneliti ingin melihat bangaimana tingkat resiko ergonomi dan keluhan subjektif Muscoluskeletal Diserdars pada pekerja bagian produksi di PT MIDPER.

Berdasarkan data yang telah disebutkan dalam latar belakang, kasus Muscoluskeletal Diserdars( MSDs) merupakan salah satu penyumbang terbesar dari semua kasus cedera atau 
sakit. Salah satu pekerjaan yang beresiko untuk terkena MSDs tersebut adalah pekerja di industri pabrik tas. Berdasarkan observasi yang dilakukan pada bulan maret 2019, ditemukan pekerja yang beresiko MSDs pada PT MIDPER salah satu industri yang bergerak dibidang pembuatan TAS, resiko tersebut timbul akibat adanya postur janggal, gerakan respetitif,dan postur statis. Oleh sebab itu, diperlukan analisis tentang tingkat resiko ergonomi dan keluhan subjektif Muscoluskeletal Diserdars pada pekerja PT MIDPER, khususnya pada bagian produksi.

Tujuan penelitian ini untuk mengetahui hubungan dengan tingkat keluhan nyeri punggung bagian bawah pada karyawan di PT Midper Kabupaten Bogor Tahun 2020. Penelitian ini di laksanakan mulai bulan November 2019 sampai bulan Maret 2020 di PT Midper, dengan jumlah keseluruhan responden sebanyak 50 orang. Penelitian ini menggunakan study deskriptif analitik yang bersifat cross sectional study dengan menggunakan metode kuantitatif, dengan variable yang di teliti usia, kebiasaan merokok, kebiasaan olahraga, postur kerja dan durasi kerja. Instrumen penelitian ini menggunakan kuesioner dan Rapid Entir Body Assesment (REBA) untuk pengukuran postur kerja. Data yang digunakan dalam penelitian ini bersumber dari data sekunder dan data primer.Teknik pengambilan sampel menggunakan teknik sample jenuh karena jumlah populasi kurang dari 100.

\section{METODE}

Penelitian ini merupakan studi deskriptif analitik yang bersifat cross sectional study dengan menggunakan pendekatan kuantitatif. Cross sectional study (potong lintang) yaitu suatu penelitian untuk mempelajari dinamika kolerasi antara faktor-faktor risiko dengan efek, dengan cara pendekatan observasi atau pengumpulan data sekaligus pada suatu saat (Notoatmodjo, 2010).

Penelitian ini menggunakan rancangan cross sectional untuk mengetahui faktor faktor yang berhubungan dengan keluhan Msds pada pekerja pabrik MIDPER Kabupaten Bogor Tahun 2019.

Variabel penelitian adalah suatu atribut atau sifat nilai dari orang, obyek, atau kegiatan yang mempunyai variasi tertentu yang ditetapkan oleh peneliti untuk dipelajari dan kemudian ditarik kesimpulannya (Sugiyono, 2012). Variable independen dari penelitian ini diantaranya faktor individual yaitu, usia, kebiasaan olahraga, masa kerja dan faktor pekerja yaitu postur, durasi kerja. Sedangkan variable dependen ini adalah keluhan Msds pada Pekerja Pabrik Tas MIDPER Tahun 2019.

Pengambilan data pada penelitian ini dilakukan di desa Cinangneng Kecematan Ciampea Kabupaten Bogor Jawa Barat, Indonesia. Penelitian ini dilakukan pada bulan November 2019 s/d Maret 2020.

Sumber - sumber atau bahan penelitian yang dapat dijadikan bahan penelitian dalam penelitian ini tentang faktor-faktor yang berhubungan dengan keluhan Msds pada pekerja pabrik tas MIDPER Kabupaten Bogor, antara lain :

Data ini didapat dengan melakukan observasi langsung dengan menggunakan kuesioner yang dibagikan kepada responden, yaitu pekerja pabrik tas MIDPER Kabupaten Bogor.

Data sekunder diperoleh dari informasi tentang riwayat Msds Di pabrik tas MIDPER 
Kabupaten Bogor, Jurnal Kesehatan Masyarakat Analisis data dilakukan untuk memperoleh gambaran dari hasil penelitian yang telah dirumuskan dalam tujuan penelitian, memberi hipotesis-hipotesis penelitian yang telah dirumuskan, serta memperoleh kesimpulan secara umum dari penelitian, yang merupakan kontribusi dalam pengembangan ilmu yang bersangkutan (Notoadmodjo, 2010). Analisis univariat merupakan analisa yang dilakukan menganalisis tiap variabel dari hasil penelitian (Notoadmodjo, 2005). Analisis univariat dilakukan untuk melihat distribusi frekuensi dan presentasi dari setiap variable yang diteliti yaitu variable independen dan dependen. Variable independen dalam penelitian ini yaitu faktor individual ( usia, masa kerja dan kebiasaan olahraga) dan faktor pekerjaan (postur, durasi kerja). Sedangkan variable dependen yaitu keluhan Msds.

Analisis ini dilakukan untuk melihat dua variable yang diduga berhubungan atau berkolerasi yaitu variable bebas (independen) berupa karakteristik individual dan pekerjaan. Variable terikat (dependent) yaitu keluhan Msds pada pekerja pabrik Tas MIDPER di 3 Kabupaten Bogor. Dengan menggunakan uji statistik chi square, uji kemaknaan dilakukan dengan menggunakan [ ] = 0,05 dan confidence interval 95\%.

\section{HASIL}

\section{Analisis Univariat}

diketahui bahwa sebagian usia > 30 tahun sebanyak 29 (58\%) dan yang < 30 tahun sebanyak 21 (42\%). diketahui bahwa ada keluhan nyeri punggung bagian bawah berkategori rendah sebanyak 29 responden (58\%), sedangkan yang berkategori tinggi sebanyak 2 responden (42\%). diketahui bahwa ada keluhan nyeri punggung bagian bawah berkategori rendah sebanyak 25 responden (50\%), sedangkan yang berkategori tinggi sebanyak 25 responden (50\%). diketahui bahwa sebagian masa kerja responden $<8$ tahun sebanyak 33 responden (62\%), sedangkan responden dengan masa kerja $>8$ tahun sebanyak 17 responden (38\%). diketahui bahwa durasi kerja responden < 8 jam dari sebanyak 17 responden (34\%) sedangkan responden yang > 8 jam sebanyak 33 responden (66\%). diketahui bahwa sebagian kebiasaan merokok ya sebanyak 20 responden (40\%), sedangkan responden dengan kebiasaan merokok tidak sebanyak 30 responden (60\%). diketahui bahwa sebagian kebiasaan olahraga ya sebanyak 3 responden (6\%), sedangkan responden dengan kebiasaan olahraga tidak sebanyak 47 responden (94\%).

\section{Analisis Bivariat}

diketahui bahwa pengaruh usia < 30 tahun dengan adanya keluhan keluhan nyeri punggung bagian bawah pada pekerja Pt Midver sebanyak 29 yang memiliki keluhan punggung sebanyak 28 responden (16,8\%) yang memiliki umur > 30 tahun sebanyak 1 responden (12,2\%), sedangkan yg tidak memiliki keluhan sebanyak 21 yang memiliki umur < 30 tahun sebanyak 1 responden (12,2\%) yang memiliki umur > 30 tahun sebanyak 20 responden $(8,8 \%)$.

Dari hasil uji statistik diperoleh nilai p-value 0,000. Oleh karena itu nilai alpha lebih kecil dari 0,05 maka dapat disimpulkan bahwa ada hubungan bermakna antara usia dengan keluhan nyeri punggung bagian bawah pada pekerja pt midver tahun 2020.

diketahui bahwa pengaruh masa kerja dengan keluhan nyeri punggung bagian bawah 
pada pekerja di atas masa kerja < 8 tahun sebanyak 31 responden memiliki keluhan punggung bagian bawah sebanyak 11 responden (18\%) yang tidak memiliki nyeri punggung bagian bawah sebanyak 20 responden (13\%), sedangkan pekerja yang memiliki masa kerja > 8 tahun sebanyak 19 responden memiliki keluhan nyeri punggung sebanyak 18 responden (11\%) yang tidak memiliki keluhan nyeri punggung sebanyak 1 responden (8\%).

Dari hasil uji statistik diperoleh nilai p-value 0,000. Oleh karena itu nilai alpha lebih kecil dari 0,05 maka dapat disimpulkan bahwa ada hubungan bermakna antara masa kerja dengan keluhan nyeri punggug bagian bawah pada pekerja pt midver tahun 2020.

diketahui bahwa pengaruh durasi kerja dengan keluhan nyeri punggung bagian bawah pada pekerja pt midper di atas > 8 jam sebanyak 29 responden memiliki keluhan nyeri punggung sebanyak 16 responden $(9,9 \%)$ yang memiliki durasi kerja < 8 jam sebanyak 13 responden $(13,1 \%)$, sedangkan yang memiliki keluhan nyeri punggung bagian bawah sebanyak 21 responden yang memiliki durasi kerja < 8 jam sebanyak 1 responden $(7,1 \%)$ dan yang memiliki durasi kerja .> 8 jamjam sebanyak $20(13,9 \%)$

Dari hasil uji statistik diperoleh nilai p-value 0,000. Oleh karena itu nilai alpha lebih kecil dari 0,05 maka dapat disimpulkan bahwa ada hubungan bermakna antara durasi kerja dengan nyeri punggung bagian bawah pada pekerja pt midver tahun 2020

diketahui bahwa pengaruh kebiasaan olahraga dengan memiliki keluhan nyeri punggung bagian bawah sebanyak 29 pada pekerja pt midver dengan kebiasaan olahraga Ya sebanyak 0 responden $(1,7 \%)$ memiliki keluhan nyeri punggung bagian bawah yang tidak memiliki kebiasaan olahraga sebanyak 29 responden $(27,3)$, sedangkan yang keluhan punggung bagian bawah berkategori tidak ada sebanyak 21 responden memiliki kebiasaan olahraga ketegori Ya sebanyak 3 responden (1,3\%) yang tidak memiliki kebiasaan olahraga sebanyak 18 responden $(19,7 \%)$.

Dari hasil uji statistik diperoleh nilai p-value 0,068. Oleh karena itu nilai alpha lebih besar dari 0,05 maka dapat disimpulkan bahwa tidak ada hubungan bermakna antara kebiasaan olahraga dengan keluhan nyeri punggung bagian bawah pada pekerja pt midver tahun 2020.

diketahui bahwa pengaruh kebiasaan merokok dengan keluhan nyeri punggung bagian bawah pada pekerja pt midper dengan kebiasaan merokok kategori Ya sebanyak 29 responden memiliki keluhan nyeri punggung bagian bawah sebanyak 19 responden $(11,6 \%)$ yang tidak memiliki kebiasaan merokok sebanyak 10 responden $(17,4 \%)$, sedangkan yang keluhan punggung bagian bawah berkategori tidak ada sebanyak 21 responden memiliki kebiasaan olahraga ketegori Ya sebanyak 1 responden $(8,4 \%)$ yang tidak memiliki kebiasaan merokok sebanyak 20 responden (11,6\%).

Dari hasil uji statistik diperoleh nilai p-value 0,000. Oleh karena itu nilai alpha lebih besar dari 0,05 maka dapat disimpulkan bahwa ada hubungan bermakna antara kebiasaan merokok dengan keluhan nyeri punggung bagian bawah pada pekerja pt midver tahun 2020 .

diketahui bahwa pengaruh postur kerja rendah dengan keluhan nyeri punggung bagian bawah pada pekerja pt midver dengan sebanyak 25 responden memiliki keluhan nyeri punggung bagian bawah sebanyak 24 responden (14,5\%) yang tidak memiliki sebanyak 1 responden $(10,5 \%)$, sedangkan yang memiliki postur kerja sedang sebanyak 25 responden memiliki keluhan nyeri punggung sebanyak 5 responden $(14,5 \%)$ yang tidak memiliki 
keluhan gangguan punggung sebanyak 20 responden (10,5\%).

Dari hasil uji statistik diperoleh nilai p-value 0,000. Oleh karena itu nilai alpha lebih besar dari 0,05 maka dapat disimpulkan bahwa ada hubungan bermakna antara kebiasaan merokok dengan keluhan nyeri punggung bagian bawah pada pekerja pt midver tahun 2020 .

\section{Hubungan Keluhan Nyeri Punggung Bagian Bawah Dengan Usia}

Tarwaka (2004) menyatakan bahwa umumnya keluhan otot skeletal mulai dirasakan pada usia kerja yaitu 35 tahun dan tingkat keluhan akan terus bertambah sejalan dengan bertambah umur.

Berdasarkan hasil penelitian bahwa terdapat hubungan bermakna antara usia dengan keluhan nyeri punggng bagian bawah terhadap pekerja Pt Midper cinangneng kabupaten Bogor dapat dilihat berdasarkan nilai $p$-value 0,000 lebih kecil dari nilai alpha sebesar 0,05 sehingga Ho di tolak dan usia terbukti berpengaruh terhadap nyeri punggung bagian bawah pada pekerja Pt Midper. Karna otot jika sudah berusia lebih dari 40 tahun akan mengalami penurunan fungsi seperti otot. Hasil penelitian ini sejalan dengan penelitian Alvira Syarafinadini (2017) dengan judul "faktor-faktor yang mempengaruhi keluhan nyeri punggung pada supir angkutan umum trayek 16 kota bogor" yaitu nilai p- value sebesar 0,008 jadi nilai p-value lebih kecil dari 0,05.

Berdasarkan hasil uji statistik di peroleh nilai OR 0,41 (95\%CI : 0,05-341) yang artinya responden yang memiliki usia $>30$ tahun akan mengalami resiko nyeri punggung bagian bawah 0,41 kali lebih besar mengalami gangguan otot dibandingkan responden yang memiliki usia $<30$ tahun. Karena usia pekerja berada pada tingkat resiko tingggi.

Berdasarkan hasil kuesioner pada pekerja di Pt Midper Kab Bogor bahwa usia > 30 tahun mempengaruhi gangguan nyeri punggung bagian bawah dikarenakan pekerja memiliki otot yang berbeda dengan yang usia $<30$ Tahun.

Berdasarkan hasil kuesioner pada pekerja Pt Midper Kab Bogor masa kerja responden < 30 tahun sejumlah 29 ( 58\%) responden dan durasi > 30tahun sejumlah 21 (42\%) responden.dan Berdasarkan hasil kuesioner pada pekerja Pt Midper Kab Bogor bahwa keluhan nyeri punggung sejumlah 29 (58\%) responden danyang tidak memiliki keluhan sejumlah $21(42 \%)$ responden.

\section{Hubungan Masa Kerja Dengan Keluhan Nyeri Punggung Bagian Bawah}

Masa kerja berpengaruh pada pekerja Pt Midper rata-rata masa kerja $<8$ tahun. Beban kerja fisik dapat mengakibatkan kelelahan pada pekerja sehingga apabila pekerja dalam kondisi lelah dan tetap bekerja maka akan berakibat mengalami kelalahan pada otot skeletal ( Amalia, 2014)

Berdasarkan hasil penelitian bahwa terdapat hubungan bermakna antara masa kerja dengan keluhan nyeri punggng bagian bawah terhadap pekerja Pt Midper cinangneng kabupaten Bogor dapat dilihat berdasarkan nilai $p$-value 0,000 lebih kecil dari nilai alpha sebesar 0,05 sehingga Ho di tolak dan masa kerja terbukti berpengaruh terhadap nyeri punggung bagian bawah pada pekerja Pt Midver. Hasil penelitian ini sejalan dengan penelitian Annisa Septiani (2017) "faktor-faktor yang berhubungan dengan Msds pada pekerja bagian Meat Preparations Pt Bumi Sinarmas Indonesia tahun 2017" dengan nilai p-value 0,000 jadi 
nilai a lebih kecil dari 0,05. Karna jika masa kerja semakin lama maka akan berdampak negatif pada otot (Suma'mur P.K, 2014 : 45)

Berdasarkan hasil uji statistik di peroleh nilai OR 0,240 (95\% CI : 3836-279,274) yang artinya responden yang memiliki masa kerja $>8$ tahun akan mengalami resiko nyeri punggung bagian bawah 0,240 kali lebih besar mengalami gangguan otot dibandingkan responden yang memiliki masa kerja $<8$ tahun. Karena masa pekerja berada pada tingkat resiko tingggi. Berdasarkan hasil kuesioner pada pekerja di Pt Midper Kab Bogor bahwa masa kerja > 8 tahun mempengaruhi gangguan nyeri punggung bagian bawah dikarenakan semakin lama seseorang dalam bekerja akan mempengaruhi otot.

\section{Hubungan Durasi Kerja Dengan Keluhan Nyeri Punggung Bagian Bawah}

Durasi Kerja berpengaruh pada pekerja Pt Midper rata-rata Durasi> 8 jam kerja. Lamanya seseorang dalam bekerja baik dengan sehari umumnya $6-10$ jam, sisanya digunakan untuk kehidupan keluarga dan masyaraka, istirahat, tidur dll. Jika seseorang bekerja dengan wwaktu yang labih lama maka akan menimbulkan penurunan kualitas kerja dan mengakibatkan kecelakaan kerja (john Ridley, 2008)

Berdasarkan hasil penelitian bahwa terdapat hubungan bermakna antara durasi kerja dengan keluhan nyeri punggng bagian bawah terhadap pekerja Pt Midper cinangneng kabupaten Bogor dapat dilihat berdasarkan nilai $p$-value 0,000 lebih kecil dari nilai alpha sebesar 0,05 sehingga Ho di tolak dan masa kerja terbukti berpengaruh terhadap nyeri punggung bagian bawah pada pekerja Pt Midper. Hasil tidak sejalan dengan penelitian Ahmad Rifki (2013) " faktor-faktor yang mempengaruhi Msds dengan pekerja sepatu di perkampungan industri kecil penggilingan kecamatan cakung tahun 2013 "dengan nilai p-value 0,576 sehingga nilai a lebih besar dari 0,05.

Berdasarkan hasil uji statistik di peroleh nilai OR 0,41 (95\% CI : 0,05-344) yang artinya responden yang memiliki durasi kerja > 8 jam akan mengalami resiko nyeri punggung bagian bawah 0,41 kali lebih besar mengalami gangguan otot dibandingkan responden yang memiliki durasi kerja $<8$ jam. Karena durasi pekerja berada pada tingkat resiko tingggi. Berdasarkan hasil kuesioner pada pekerja di Pt Midper Kab Bogor bahwa durasi kerja > 8 jam mempengaruhi gangguan nyeri punggung bagian bawah dikarenakan semakin lama seseorang dalam bekerja akan mempengaruhi otot.

\section{Hubungan Kebiasaan Olahraga Dengan Keluhan Nyeri Punggung Bagian Bawah}

Tingkat jasmani yang lemah maka akan maka akan meningkatkan resiko terjadinya keluhan otot (Haljaste, dan Unt 2010). Berdasarkan NOISH diikuti dari hasil penelitian candy (1979) menyebutkan bahwa untuk meningkatkan tingkat jasmani yang rendah akan mengakibatkan keluhan nyeri otot bagian bawah Berdasarkan hasil penelitian bahwa terdapat hubungan bermakna antara kebiasaan olahraga dengan keluhan nyeri punggng bagian bawah terhadap pekerja Pt Midper cinangneng kabupaten Bogor dapat dilihat berdasarkan nilai $p$-value 0,068 lebih besar dari nilai alpha sebesar 0,05 sehingga Ho gagal ditolak dan kebiasaan olahraga terbukti tidak berpengaruh terhadap nyeri punggung bagian bawah pada pekerja Pt Midver. Hasil penelitian ini tidak sejalan dengan Hikka R (1998) "Musculoskeletal Sytem Of Occoputional Health and Safety" Menyatakan bahwa orang-orang 
dengan kesehatan jasmani paling rendah dapat mengalami peningkatan bahaya kesehatan terhadap cedera punggung. Karna jika tingkat jasmani lemah maka akan berdampak negatif pada otot.

Berdasarkan hasil uji statistik di peroleh nilai OR 2,611 (95\% CI : 1,816-3,753). Berdasarkan hasil kuesioner pada pekerja di Pt Midper Kab Bogor bahwa tingkat jasmani mempengaruhi gangguan nyeri punggung bagian bawah dikarenakan semakin lemah tubuh seseorang dalam bekerja akan mempengaruhi otot.

Berdasarkan hasil kuesioner, responden kebiasaan olahraga baik yaitu sebanyak 3 (6\%) responden dan responden memiliki kebiasaan olahraga buruk sebanyak 47 (94\%) responden.

\section{Hubugan Postur Tubuh Dengan Keluhan Gangguan Nyeri Punggung Bagian Bawah}

Pheasant (1991) menunjukan bahwa postur kerja yg statis dalam jangka waktu yang lebih lama lebih cepat menimbulkan keluhan pada sistem otot skeletal. Pekerja dengan postur kerja duduk lebih yang baik akan lebih tidak berpengaru terhadap ganggungan punggung ( Eko,2016)

Berdasarkan hasil penelitian bahwa terdapat hubungan bermakna antara postur kerja dengan keluhan nyeri punggng bagian bawah terhadap pekerja Pt Midper cinangneng kabupaten Bogor dapat dilihat berdasarkan nilai $p$-value 0,000 lebih kecil dari nilai alpha sebesar 0,05 sehingga Ho di tolak dan masa kerja terbukti berpengaruh terhadap nyeri punggung bagian bawah pada pekerja Pt Midper. Hasil penelitian ini sejalan dengan penelitian Endang Bukhori (2010) “ Hubungan faktor resiko pekerjaan dengan terjadinya keluhanMsds pada tukang angkut bebean penambang emas dikecamatan Cilongrang Kabupaten Lebak Tahun 2010". Dikatan bahwa nilai p-value sebesar 0,029 jadinilai a ebih kecil dari 0,05. Karna jika merokok akan mengurangi mineral dalam tulang maka akan berdampak negatif pada otot.

Berdasarkan hasil uji statistik di peroleh nilai OR 0,10 (95\% CI : 0,01- 0,97) yang artinya responden yang memiliki postur kerja akan mengalami resiko nyeri punggung bagian bawah 0,10 kali lebih besar mengalami gangguan otot dibandingkan responden yang memiliki postur kerja baik.

Berdasarkan hasil kuesioner, responden postur kerja rendah yaitu sebanyak 25 (50\%) responden dan responden memiliki kebiasaan olahraga buruk sebanyak 25 (50\%) responden.

\section{Hubugan Kebiasaan Merokok Dengan Keluhan Gangguan Nyeri Punggung Bagian Bawah}

Kebiasaan merokok menjadi faktor resiko pada pekerjaan yang memerlukan pengerahan otot karna nikotin pada rokok dapat menyebabkan berkurangnya aliran darah ke jaringan. Selain itu merokok dapat menyebabkan berkurangnya kandungan mineral pada tulang sehingga meneyebabkan nyeri pada tulang (Kantana, 2010).

Berdasarkan hasil penelitian bahwa terdapat hubungan bermakna antara kebiasaan merokok dengan keluhan nyeri punggng bagian bawah terhadap pekerja Pt Midper cinangneng kabupaten Bogor dapat dilihat berdasarkan nilai $p$-value 0,000 lebih kecil dari nilai alpha sebesar 0,05 sehingga Ho di tolak dan masa kerja terbukti berpengaruh terhadap nyeri punggung bagian bawah pada pekerja Pt Midver. Hasil penelitian ini tidak sejalan 
dengan penelitian yang dilakukan oleh Emi Maujunidah (2010), "faktor-faktor yang mempengaruhi keluhan Msds pada pekerja Assembling Pt X Kota Bogor. Dikatakan bahwa faktor kabiasaan merokok tidak berpengaruh dengan Msds walaupun berdasarkan data bahwa mayoritas respponden perokok yaitu sebanyak 36 orang(51,4\%). Karna jika merokok akan mengurangi mineral dalam tulang maka akan berdampak negatif pada otot.

Berdasarkan hasil uji statistik di peroleh nilai OR 0,26 (95\% CI : 0,03-0,226) yang artinya responden yang memiliki kebiasaan merokok buruk akan mengalami resiko nyeri punggung bagian bawah 0,200 kali lebih besar mengalami gangguan otot dibandingkan responden yang memiliki kebiasaan merokok kurang.

\section{KESIMPULAN}

Berdasarkan hasil penelitian yang dilaksanakan di Pt Midper Cinangneng Kabupaten Bogor pada bulan November 2019 sampai Februari 2020 mengenai Hubungan resiko ergonomi dengan kajadian MSDs di Pt Midper Cinangneng Kabupaten Bogor dari 50 responden didapat sebagai berikut Adanya hubungan antara usia dengan keluhan nyeri punggung bagian bawah yaitu dengan nilai p-value 0,000. Dalam penelitian ini semakin bertambahnya usia maka keluhan nyeri punggung akan semakin terasa karn otot yang mulai melemah.

Adanya hubungan antara masa kerja dengan keluhan nyeri punggu bagian bawah dengan nilai p-value 0,000 . Dalam penelitian ini terbukti bahwa masa kerja yang semaki lama maka akan menyebabkan keluhan nyeri punggung bagian bawah.

Adanya hubungan antara kebiasaaan merokok dengan keluhan nyei punggung bagian bawah dengan nilai p-value 0,000. Dalam penelitian ini merokok dapat mengakibatkan keluha nyeri punggung karna didalam rokok dapat menyebabkan otot menjadi lemah.

Tidak ada hubungan antara kebiasaan olahraga dengan keluhan nyeri punggung bagian bawah dengan nilai p-value 0,068. Dalam penelitian ini jarangnya olahraga tidak mempengaruhi keluhan nyeri punggung.

Adanya hubungan antara durasi kerja dengan keluhan nyeri punggung bagian bawah dengan p-value 0,000. Dalam penelitian ini semakin jam kerja maka akan semakin berresiko mengalami keluhan nyeri punggung bagian bawah.

Adanya hubungan antara postur kerja dengan keluhan nyeri punggung bagian bawah dengan nilai -value 0,000.dalam penelitian ini postur kerja yang tidak ergonomis akan menyebabkan otot manjadi kaku atau mengalami keluhan

\section{Saran}

Diberikan sosialisasi tentang ergonomi yang baik dalam bekerja bisa melalui poster atau slide agar pekerja dapat bekerja sesuai dengan ergonomi. Sehingga terciptanya lingkungan kerja yang aman dan produktif. seminar atau penyuluhan di perusahaan-perusahan produksi mengenai bekerja dengan ergonomis sehingga dapat menyebarkan ilmu pengetahuan lebih luas lagi. 


\section{DAFTAR PUSTAKA}

Avianty, I., Luthfi, F., Suharto,„...Ginanjar, R., Nasution, A.S. (2021). Nutritional status, dust exposure and risk factors for acute respiratory infections for workers in industrial estates. Indian Journal of Forensic Medicine and Toxicologythis link is disabled, 2021, 15(1), pp. 1156-1160

Afrilyani, R.,Supriyanto \& Ginanjar, R. 2019. Gambaran Kepatuhan Petugas Laboratorium Terhadap Penggunaan Alat Pelindung Diri di Rumah Sakit Salak Bogor Tahun 2017. Jurnal Mahasiswa Kesehatan Masyarakat, 2 (4): 306-312

A Nasution, A Maulana, D Kurniawan. (2019). BERSAMA MEMAJUKAN DESA. Abdi Dosen: Jurnal Pengabdian Pada Masyarakat 3 (2), 99-104

Fitrianingtyas, Pertiwi, dan Rachmania, W. Faktor-Faktor yang Berhubungan dengan Kejadian Kurang Energi Kronis (KEK) pada Ibu Hamil di Puskesmas Warung Jambu Kota Bogor. HEARTY Jurnal Kesehatan Masyarakat. 2018;6(2):1-8.

Fadilah, D., Supriyanto, Ginanjar, R. 2018. Faktor-Faktor Yang Berhubungan Dengan Perilaku Pemakaian Helm Pengendara Sepeda Motor Pada Pelajar Kelas X (Sepuluh). PROMOTOR: Jurnal Mahasiswa Kesehatan Masyarakat, 1(1): 29-36.

Ginanjar, R., Fathimah, A., \& Aulia, R. 2018. Analisis Risiko Ergonomi Terhadap Keluhan Musculoskeletal Disorders (MSDs) Pada Pekerja Konveksi Di Kelurahan Kebon Pedes Kota Bogor Tahun 2018. Jurnal Mahasiswa Kesehatan Masyarakat, 1(2).

Pertiwi, F. D., Hariansyah, M., \& Prasetya, E. P. (2019). FAKTOR RISIKO STUNTING PADA BALITA DIKELURAHAN MULYAHARJA TAHUN 2019. PROMOTOR, 2(5). https://doi.org/10.32832/pro.v2i5.2531

Pertiwi, F. D., Rahman, R. M., \& Lestari, D. W. (2018). Pemberdayaan masyarakat melalui bidang literasi di Desawaru Jaya. Jurnal ABDI DOSEN: Jurnal Pengabdian Pada Masyarakat, 2(2), 129-137. https://doi.org/10.32832/abdidos.v2i2.170

Pratama S., Asnifatima A., Ginanjar R., 2019, Faktor-Faktor Yang Berhubungan Terhadap Postur Kerja Dengan Keluhan Nyeri Punggung Bawah Pada Pengemudi Bus Pusaka Di Terminal Baranangsiang Kota Bogor Tahun 2018, Promotor Jurnal Mahasiswa Kesehatan Masyarakat Vol.2, No.4

Puspitasari, S. Supriyanto. Ginanjar, R. (2019). Faktor-Faktor yang Berhubungan dengan Kecelakaan Kerja Tertusuk Jarum Suntik atau Benda Tajam Lainnya Pada Perawat di RSUD Leuwiliang Kabupaten Bogor Tahun 2018. Promotor Jurnal Mahasiswa Kesehatan Masyarakat, 2(2), 163-171.

Raya, M. R., Asnifatimah, A. and Ginanjar,R. 2018. Faktor-Faktor yang Mempengaruhi

Keluhan Gangguan Pendengaran Pada Supir Bus POPusaka Di Terminal BaranangsiangKota Bogor Tahun 2018.JurnalPromotor Vol 2 No 2.

Supriyanto, RA Nugraha, R Ginanjar. (2018). KAJIAN SISTEM PROTEKSI DAN PENANGGULANGAN KEBAKARAN DI STASIUN PENGISIAN BAHAN BAKAR UMUM (SPBU) DIJALAN KEDUNGHALANG RAYA, KOTA BOGOR UTARA TAHUN 2018. PROMOTOR 1 (2), 130-139

Sugiyono, (2014) Metode Penelitian Pendidikan Pendekatan Kuantitatif, Kualitatif Dan R\&D. Bandung. Alfabeta.

Sugiono, (2009) Metode Penelitian Bisnis(Pendekatan Kuantitatif, Kualitatif, Dan 
R\&D).Bandung.Alfabeta.

Tarwaka, Dkk (2004) Ergonomi Untuk Keselamatan, Kesehatan Kerja Dan Produktivitas, Uniba Press, Surakarta.

Tarwaka, Solichul Ha Bakri, Lilis Sudiajeng (2004) Ergonomi Untuk Keselamatan Kesehatan Kerja Dan Produktivitas, Surakarta : Universitas Brawijaya, Press 